\title{
INFLUENCE OF ULTRASONIC IMPACT TREATMENT ON THE FATIGUE SAFETY COEFFICIENTS OF WELDED JOINTS OF THE STRENX 700MC STEEL
}

\author{
UDC: 621.791 .754 \\ 620.174 \\ Original scientific paper \\ https://doi.org/10.18485/aeletters.2020.5.3.1 \\ Daniel Varecha ${ }^{1^{*}}$, Otakar Bokůvka ${ }^{2}$, Libor Trško ${ }^{3}$, Martin Vicen ${ }^{2}$, Ružica R. Nikolić ${ }^{3}$ \\ ${ }^{1}$ University of Žilina, Faculty of Mechnaical Engineering, Department of Design and Mechanical Elements, \\ Slovakia \\ ${ }^{2}$ University of Žilina, Faculty of Mechnaical Engineering, Department of Materials Engineering, Slovakia \\ ${ }^{3}$ University of Žilina, Research Center, Slovakia
}

\begin{abstract}
:
Research results of influence of the UIT (Ultrasonic Impact Treatment) on welded joints, executed on the Strenx $700 \mathrm{MC}$ steel, are presented in this paper. The fatigue tests of those joints were performed by rotating bending in the region of the high number of loading cycles $\left(10^{5}\right.$ to $\left.10^{7}\right)$ with parameters: frequency $35 \mathrm{~Hz}$, cycles asymmetry factor -1 , at the ambient temperature $20 \pm 2{ }^{\circ} \mathrm{C}$. The fatigue safety coefficient was calculated before the UIT (in the original state) and after the UIT, according to four methods. An increase was recorded for the latter state: for the Goodman method of $10.45 \%$, for the Gerber method of $10.21 \%$, for the ASME method of $5.96 \%$ and for the Soderberg method of $7.40 \%$.
\end{abstract}

\section{ARTICLE HISTORY}

Received: 14.07.2020.

Accepted: 26.08 .2020

Available: 30.09.2020.

\section{KEYWORDS}

Strenx $700 \mathrm{MC}$ steel, high-

cycles fatigue, safety

coefficients

\section{INTRODUCTION}

During the operation under the cyclic loading, the structural elements are experiencing degradation of the material's useful properties due to fatigue. It is recorded that over $90 \%$ of all the fractures of various components are caused by fatigue of materials they are made of. Theoretical and experimental research of the high-cycle fatigue of construction materials began in the mid$19^{\text {th }}$ century. The degradation fatigue mechanism, the initiation of fatigue failure in the area of highcycles fatigue, usually occurs on the surface or at a small depth below the surface [1-9]. Increase in the fatigue resistance is therefore oriented primarily to improve the mechanical properties of the surface layers of construction materials. To that purpose various surface treatment procedures like thermal (surface hardening), chemical-thermal (cementing, nitriding), mechanical (shot peening, severe shot peening, ultrasonic impact peening) and others are implemented. Ultrasonic impact peening is a progressive method in which the surface layer is subjected to cold plastic deformation, the introduction of compressive residual stresses into the surface layers. The increase in fatigue strength is usually up to $20 \%$ [ 8 , $10-15]$. Weldable steels with an increased yield strength (e.g. Strenx 700MC, Hardox 400, Hardox 450 ....) are recommended for use in the transport engineering, cranes, military industry and so on. Due to such applications, those steels are subjected to high demands in terms of durability, safety and reliability. However, welds are special places since the weld is a point of a highly inhomogeneous microstructure, a place of preferential initiation and growth of fatigue failure [16 - 18]. Application of the ultrasonic impact peening in the case of welds can lead to an increase in fatigue strength, which has a positive effect on the fatigue safety coefficients. Considering those facts, it is evident that determination of the fatigue safety coefficients $k_{u}$ is important both from theoretical and practical points of view [19-23]. In this paper, the authors are presenting results on influence of the ultrasonic impact treatment on the fatigue safety coefficients $k_{u}$ of welded Strenx 700MC steel. 


\section{EXPERIMENTAL PROCEDURE}

Experimental works included the qualitative and quantitative chemical analysis, tensile test, welding, ultrasonic impact treatment (UIT), fatigue test, as well as calculations of the fatigue safety coefficient $k_{u}$ s of the structural steel Strenx 700MC. Chemical analysis was performed by the spark emission SPECTROMAXx device. The tensile tests were carried out on the INSTRON 5985 tensile testing machine at ambient temperature of $T=20$ $\pm 2{ }^{\circ} \mathrm{C}$, with the loading range interval $F=0-20 \mathrm{kN}$ and the strain rate of $\dot{\varepsilon}_{m}=10^{-3} \mathrm{~s}^{-1}$. The round cross-section specimens were used, the shape and dimension of specimens were set according to requirements of the EN 10002-1 standard (three specimens were tested). The welding was carried out by the MAG technique under the $\mathrm{CO}_{2}$ protective atmosphere with the ESAB OK Aristrod 69 filler material $(0.08 \% \mathrm{C}, 0.60 \% \mathrm{Si}, 1.60 \% \mathrm{Mn}$, $0.25 \% \mathrm{Mo}, 0.30 \% \mathrm{Cr}, 1.40 \% \mathrm{Ni}, 0.07 \% \mathrm{~V}, R_{e}=730$ $\mathrm{MPa}, R_{m}=800 \mathrm{MPa}$, elongation $\left.=19 \%\right)$. The $60^{\circ} \mathrm{V}$ shape weld, with a single root bead, two filling beads and one covering bead was performed on a $10 \mathrm{~mm}$ thick sheet metal. Consequently test specimens according to Fig. 1 were machined from the welded sheet metal plates.

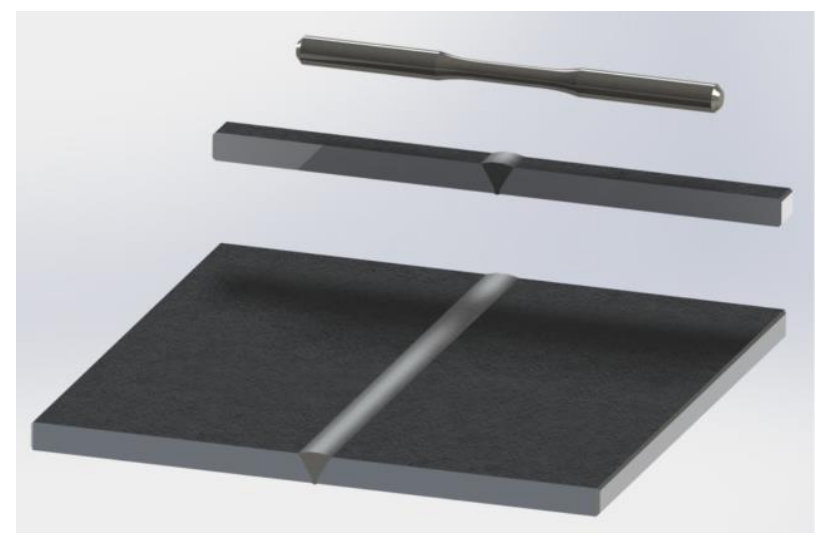

Fig. 1. Visualization of the specimen manufacturing from the $10 \mathrm{~mm}$ thick sheet metal plates

Surface of the specimens was treated by the UIT equipment with the $85 \mathrm{~N}$ pressure force and double passing the treated area (UIT $2 \times 85 \mathrm{~N}$ ). The fatigue tests were carried out on the rotating bending testing device ROTOFLEX, operating at frequency $f=35 \mathrm{~Hz}$, cycles asymmetry $R=-1$ and the ambient temperature of $T=20 \pm 2{ }^{\circ} \mathrm{C}$. Specimens (20 pieces) for the fatigue testing were taken from the welded joints, prepared by welding of $10 \mathrm{~mm}$ thick Strenx 700MC sheets. The investigated region of number of cycles $N$ ranged from $10^{5}$ to $10^{7}$ cycles of loading. The fatigue safety coefficient $k_{u}$ was calculated with regard to work [22], Fig.2, using equations (1) to (4) for the Goodman, Gerber, ASME and Soderberg methods, respectively.

$k_{u}=1 /\left(\frac{\sigma_{a}}{\sigma_{c}^{\prime}}+\frac{\sigma_{m}}{R_{m}}\right)$

$k_{u}=\frac{1}{2}\left(\frac{R_{m}}{\sigma_{m}}\right)^{2}\left(\frac{\sigma_{a}}{\sigma_{c}^{\prime}}\right)\left[-1+\sqrt{1+\left(\frac{2 \sigma_{m} \sigma_{c}^{\prime}}{R_{m} \sigma_{a}}\right)}\right]$

$k_{u}=\sqrt{1 /\left[\left(\frac{\sigma_{a}}{\sigma_{c}^{\prime}}\right)+\left(\frac{\sigma_{m}}{R_{e}}\right)^{2}\right]}$

$k_{u}=1 /\left(\frac{\sigma_{a}}{\sigma_{c}^{\prime}}+\frac{\sigma_{m}}{R_{e}}\right)$,

where:

$\sigma_{a}$ is the stress amplitude, $\sigma_{m}$ is the mean stress,

$\sigma_{c}^{\prime}$ is the fatigue limit,

$R_{m}$ is the ultimate tensile strength and $R_{e}$ is the yield point.

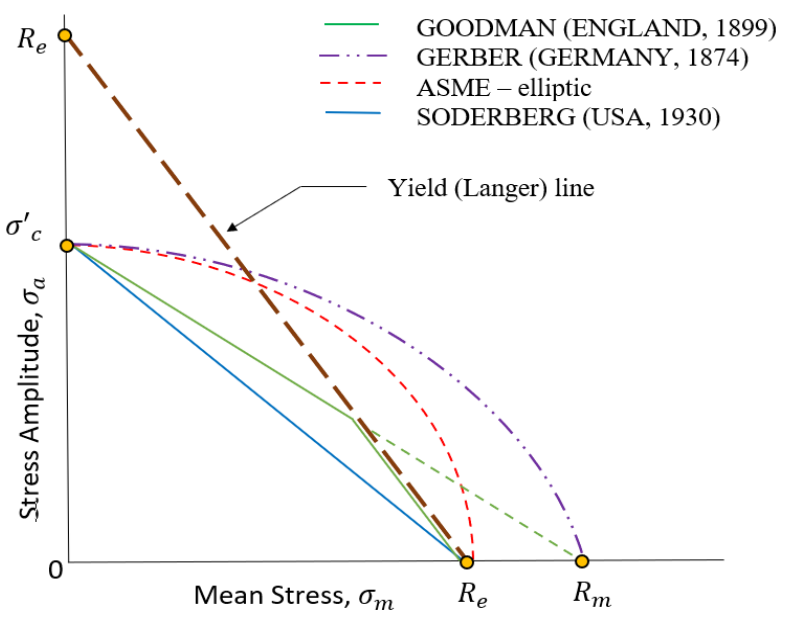

Fig. 2. Fatigue safety coefficient in terms of the stress amplitude, calculated according to four different methods [22]

Application of the described experimental works was executed on a screw joint, which is, during the operation, loaded by a cyclic stress in superposition with the preload. The material parameters of the screw are presented in Table 2, where values of the yield point and ultimate tensile strength of experimental material are given. 


\section{RESULTS AND DISCUSSION}

Results of qualitative and quantitative chemical analysis (chemical composition), tensile test (yield point, ultimate tensile strength, elongation), fatigue tests, are shown in Tables 1 and 2. Results of the fatigue safety coefficients $k_{u}$ calculations are shown in Table 3 and Fig. 3 to 6.

Table 1. Chemical composition (in weight \%) of tested structural Strenx $700 \mathrm{MC}$ steel

\begin{tabular}{|c|c|c|c|c|}
\hline $\mathbf{C}$ & $\mathbf{S i}$ & $\mathbf{M n}$ & $\mathbf{S}$ & $\mathbf{P}$ \\
\hline 0.11 & 0.093 & 0.64 & 0.017 & 0.009 \\
\hline $\mathrm{Al}$ & $\mathrm{Nb}$ & $\mathrm{V}$ & $\mathrm{Ti}$ & $\mathrm{Fe}$ \\
\hline 0.017 & 0.088 & 0.19 & 0.14 & balance \\
\hline
\end{tabular}

Table 2. Mechanical properties of tested structural Strenx 700MC steel

\begin{tabular}{|c|c|c|c|c|}
\hline $\begin{array}{c}\text { Yield } \\
\text { point, } \\
R_{e} \\
{[\mathrm{MPa}]}\end{array}$ & $\begin{array}{c}\text { Ultimate } \\
\text { tensile } \\
\text { strength, } \\
R_{m} \text { [MPa] }\end{array}$ & $\begin{array}{c}\text { Elongatio } \\
\text { n [\%] }\end{array}$ & $\begin{array}{c}\sigma_{a} \\
10^{5} \\
{[\mathrm{MPa}]}\end{array}$ & $\begin{array}{c}\sigma_{a} \\
10^{7} \\
{[\mathrm{MPa}]}\end{array}$ \\
\hline \multirow{4}{*}{741} & \multirow{4}{*}{823} & \multirow{4}{*}{11.5} & \multicolumn{2}{|c|}{ Welded } \\
\hline & & & 408 & 372 \\
\hline & & & \multicolumn{2}{|c|}{$\begin{array}{c}\text { Welded + UIT } 2 \\
\text { x } 85 \mathrm{~N}\end{array}$} \\
\hline & & & 434 & 419 \\
\hline
\end{tabular}

Table 3. Fatigue safety coefficients $k_{u}$

\begin{tabular}{|c|c|c|c|c|}
\hline $\begin{array}{c}\text { Fatigue } \\
\text { safety } \\
\text { coefficient }\end{array}$ & Goodman & Gerber & ASME & Soderberg \\
\hline $\begin{array}{c}\left(k_{u}\right)_{10^{5}} \\
\text { Welded, } \\
\text { original } \\
\text { state }\end{array}$ & 1.50 & 1.68 & 1.48 & 1.42 \\
\hline $\begin{array}{c}\left(k_{u}\right)_{10^{5}} \\
\text { Welded }+ \\
\text { UIT } \\
2 \times 85 \mathrm{~N}\end{array}$ & 1.63 & 1.84 & 1.56 & 1.50 \\
\hline $\begin{array}{c}\left(k_{u}\right)_{10^{7}} \\
\text { Welded, } \\
\text { original } \\
\text { state }\end{array}$ & 1.46 & 1.65 & 1.46 & 1.39 \\
\hline $\begin{array}{c}\left(k_{u}\right)_{10^{7}} \\
\text { Welded }+ \\
\text { UIT } \\
2 \times 85 \mathrm{~N}\end{array}$ & 1.62 & 1.82 & 1.55 & 1.49 \\
\hline
\end{tabular}

The chemical composition and mechanical properties of Strenx 700MC steel (Tables 1, and 2) fulfil requirements for the EN S700MC steels, according to the EN-10149-2 standard. Application of the ultrasonic impact peening led to an increase in fatigue strength, in the case of the $N=10^{5}$ loading cycles by $6.3 \%$; in the case of the $N=10^{7}$ loading cycles by $12.6 \%$ (Table 2 ).

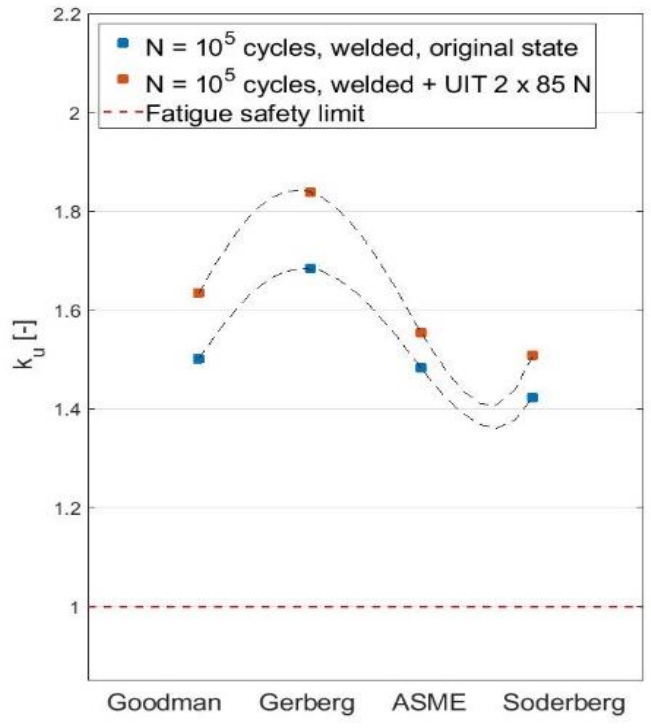

Fig. 3. Fatigue safety coefficients $k_{u}$ comparison at $N=10^{5}$ loading cycles

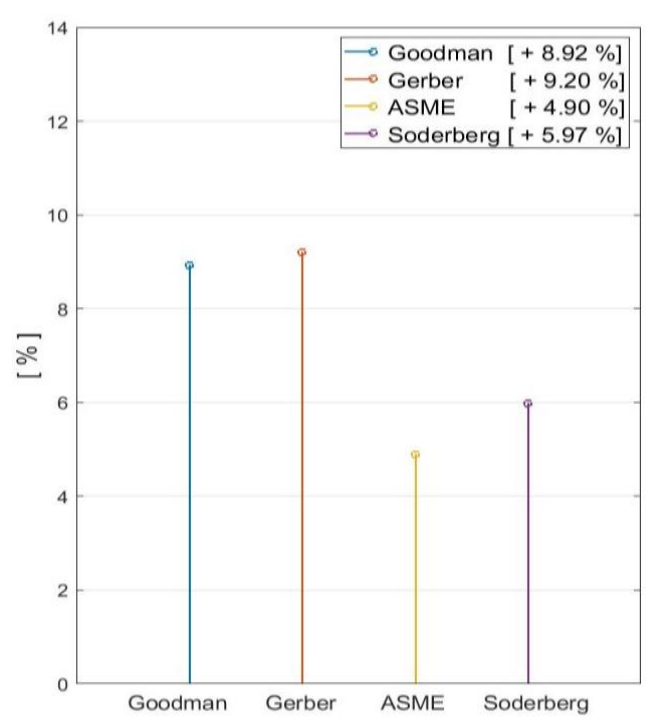

Fig. 4. Fatigue safety coefficients $k_{u}$ percentage increase

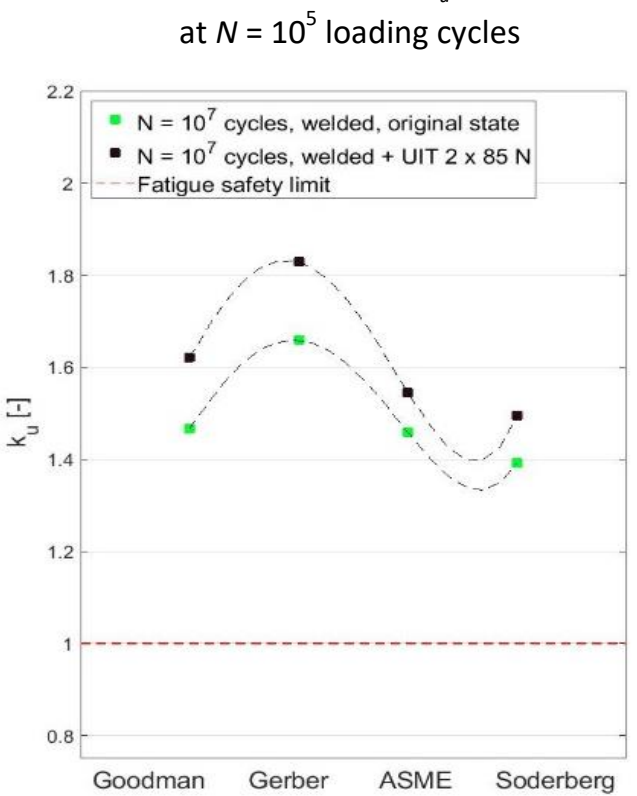

Fig. 5. Fatigue safety coefficients $k_{u}$ comparison at $N=10^{7}$ loading cycles 


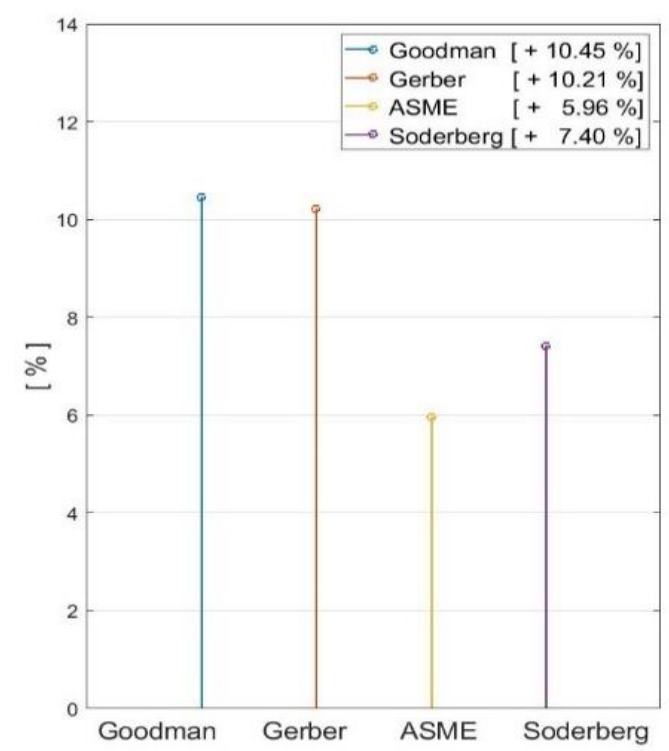

Fig. 6. Fatigue safety coefficients $k_{u}$ percentage increase, at $N=10^{7}$ loading cycles

These facts are in accordance with works [8-15], where the values within $20 \%$ are reported. The positive result of increased fatigue strength is the surface layer strengthening by the cold plastic deformation. Residual stresses are induced in the surface layers of materials and these stresses can reach the yield strength values (usually in depth of 0.1 to $0.2 \mathrm{~mm}$ ). During the plastic deformation, in the surface layer of materials, appear changes in the shape and dimensions of grains, which are among the most important microstructural factors. Grain boundaries are insurmountable barriers to movement of dislocations; they are places of dislocations pileups. In addition, the grain boundaries are often sources of dislocations, sites of exclusion of the admixture elements and secondary phases. The results are increases in the yield strength, ultimate strength limit and hardness [7, 8- 16]. The fatigue safety coefficients $k_{u}$, Table 3, Fig. 3 to 6 , were calculated by the four methods (Goodman, Gerber, ASME and Soderberg). An increase of the fatigue safety coefficient $k_{u}$ was recorded due to application of the ultrasonic impact treatment. In the case of the loading cycles number $N=10^{5}$ the fatigue safety coefficient has increased from $4.90 \%$ to $9.20 \%$, while in the case of the loading cycles number $N=10^{7}$ the increase was from $5.96 \%$ to $10.45 \%$. The percentage increase in the fatigue safety coefficients $k_{u}$ represents the fatigue reserve. The percentage increase of the fatigue safety coefficient was lower when the ASME and Soderberg methods were applied. Those methods are checking for occurrence of any deformation. In their respective equations, (3) and (4), the value of the yield point
$R_{e}$ is taken into account in the calculations and not the ultimate tensile strength $R_{m}$. The Goodman method is very strict, however, it is one of the best-known methods that allows for a single analytical solution of fatigue tasks. The Gerber method seems to be the least suitable, since it allows for approaching the limit state of the fatigue safety when the fatigue fracture accidents may occur, $[22,23]$.

\section{CONCLUSIONS}

From the performed experimental work and calculations of the fatigue safety coefficient, the following conclusions may be drawn:

- Application of the surface strengthening of the test specimens with welded joint by the ultrasonic impact treatment increased the fatigue strength in the region of the highcycles fatigue (at $N=10^{5}$ loading cycles the increase was $6.3 \%$ and at $\mathrm{N}=10^{7}$ loading cycles the increase was $12.6 \%$ ).

- The increase in fatigue safety coefficient $k_{u}$ was within range from $4.90 \%$ to $9.20 \%$ (at $N$ $=10^{5}$ loading cycles) and from $5.96 \%$ to $10.45 \%$ (at $N=10^{7}$ loading cycles); the difference appeared depending on the applied calculation method (Goodman, Gerber, ASME or Soderberg). The best results were obtained by the Goodman method.

- The enumerated facts can recommend the Strenx 700MC steel as a qualified choice for construction of components, which would operate in the region of high-cycles loading conditions.

\section{ACKNOWLEDGMENT}

The research was supported by the projects No. APVV - 16 - 0276, APVV - 18 - 0450, VEGA No 1/0951/17 and project KEGA no. $012 \mathrm{ZU}-4 / 2019$ and by the project of Operational Program Research and Innovation: "Research and development activities of the University of Žilina in the Industry of $21^{\text {st }}$ century in the field of materials and nanotechnologies", No. 313011T426, co funded by the European Regional Development Fund.

\section{REFERENCES}

[1] O. Bokůvka, G. Nicoletto, L. Kunz, P. Palček, M. Chalupova, Low and High Frequency Fatigue Testing, EDIS ŽU Žilina, 2002.

[2] O. Bokůvka, G. Nicoletto, M. Guagliano, L. Kunz, P. Palček, F. Nový, M. Chalupová, Fatigue of Materials at Low and High 
Frequency Loading EDIS ŽU Žilina, 2014.

[3] P. Kopas, F. Nový, Fatigue Life of Structural Steels with Increased Strength Limit, GEORG Žilina, (In Slovak), 2018.

[4] F. Nový, M. Chalupová, M. Činčala, O. Bokůvka, Influence of Surface Quality on the Fatigue Crack Initiation. Acta Mechanica Slovaca, 12 (4-B), 2008: 209-214.

[5] Y. Murakami, Metal Fatigue Effect of Small Defect and Nonmetallic Inclusions, Elsevier, Oxford, 2002.

[6] A. Vaško, J. Belan, L. Kuchariková, E. Tillová, Low and High Frequency Test of Nodular Cast Iron. Metalurgija - Metallurgy, 56 (1-2), 2017: 25-28.

https://hrcak.srce.hr/168845

[7] P. Skočovský, O. Bokůvka, R. Konečná, E. Tillová, Material Science, EDIS ŽU Žilina, (In Slovak), 2014.

[8] M. Holzmann, M. Klesnil, Brittle and Fatigue Fracture of Materials and Construction, SNTL Prague, (In Czech), 1972.

[9] L. Trško, O. Bokůvka, M. Jambor, f. Nový, A. Bača, Z. Florková, High and Ultra-high Cycle Fatigue of C55 High Grade Carbon Steel. Applied Engineering Letters, 1 (4), 2016: 111114.

[10] S. Baiker, Shot Peening - A Dynamic Application and Its Future, MFN Publishing, Wetzikon, Mumbai, 2012.

[11] L. Trško, O. Bokůvka, M. Guagliano, F., Nový, Effect of Severe Shot Peening on Ultra-high Cycle Fatigue of Low-Alloy Steel. Material and Design, 57, 2014: 103-113. https://doi.org/10.1016/i.matdes.2013.12.03 5

[12] L. Trško, M. Guagliano, O. Bokůvka, F. Nový, Fatigue Life of AW7075 Aluminium Alloy after Sever Shot Peening Treatment with Different Intensities. Procedia Engineering, 74, 2014: 246-252.

https://doi.org/10.1016/j.proeng.2014.06.257

[13] L. Trško, M. Guagliano, P. Lukáš, O. Bokůvka, F. Nový, Effects of Severe Shot Peening on the Surface State of AW7075 Al Alloy. Kovové materiály - Metalic Materials, 53 (4), 2015:
239-243.

https://doi.org/10.4149/km 20154239

[14] D. Závodská, M. Guagliano, O. Bokůvka, L. Trško, Effect of Shot Peening on the Fatigue Properties of 40NiCrMo7 Steel. Manufacturing Technology, 16 (1), 2016: 295299.

https://doi.org/10.21062/ujep/x.2016/a/1213 -2489/MT/16/1/295

[15] L. Trško, S. Fintová, F. Nový, O. Bokůvka, M. Jambor, F. Pastorek, Z. Florková, M. Oravcová, Study of Relation Between Shot Peening Parameters and Fatigue Fracture Surface Character of an AW7075 Aluminium Alloy. Metals, 8 (2), 2018: 111. https://doi.org/10.3390/met8020111

[16] P. Skočovský, P. Palček, R. Konečná, L. Várkoly, Construction of Materials, EDIS ŽU Žilina, (In Slovak), 2000.

[17] J. Meško, J. Veselko, Welding and Repair of Graphitic Cast Iron, EDIS ŽU Žilina, (In Slovak), 1999.

[18] I. Hrivňák, Theory of Weldability and Alloys, SAV Bratislava, (In Slovak), 1989.

[19] F. Nový, R. Ulewicz, O. Bokůvka, L. Trško, J. Lago, Reliability and Safety of Structural Elements in the Gigacycle Region of Loading. Communications - Scientific Letters of the University of Žilina, 20 (3), 2016: 15-18.

[20] R. Ulewicz, M. Mazur, Fatigue Testing of Structural Steels as a Factor of Safety of Technical Facilities Maintenance. Production Engineering Archives, 1 (1), 2013: 32-34.

[21] L. Faturík, S. Hrček, L. Trško, O. Bokůvka, Comparison of Structural Design in High and Ultra-High Cycle Fatigue Region. Transactions of FAMENA, 38 (4), 2014: 1-12. https://hrcak.srce.hr/135872

[22] R. G. Budynas, J. K. Nisbett, J. E. Shigley, Shigley's Mechanical Engineering Design, McGraw-Hill, New York, 2011.

[23] R. A. Gujar, S. V. Bhaskar, Shaft Design under Fatigue Loading by Using Modified Goodman Method. International Journal of Engineering Research and Applications, 3 (4), 2013: 10611066. 